\title{
CASE STUDY OF THE IMAPCT OF SEEPAGE AND GROUND WATER ON THE STABILITY OF MINE SLOPES
}

\author{
G.S Kate ${ }^{1}$, M.Aruna ${ }^{2}$ \\ ${ }^{1}$ Assistant Professor Civil Engineering Department ADCET Ashta 416301 India \\ ${ }^{2}$ Associate ProfessorDepartment of Mining Engineering, NITK-Surathkal 575025 India
}

\begin{abstract}
The present study is focussed on the investigation of the impact of seepage and ground water on the stability of mine slopes. Case study of three iron ore mines have been considered in Goan region. Out of three mines under consideration at one mine the effect of groundwater was observed and in remaining two mines the effect was not prominent. In this study, GALENA software were used for limit equilibrium method. From the mines rock/soil samples were collected and they are tested for determining the physio-mechanical properties like density, cohesion, angle of internal friction, young's modulus and Poisson's ratio. Using the results of laboratory studies, analysis of pit slopes have been carried out using GALENA software. Wherever, the existing/planned ultimate pit slopes angles are not stable, i.e. if their factor of safety (FOS) is below 1.3, proper measures for improving their stability were suggested.
\end{abstract}

Keywords: Limit Equilibrium Method, Pit Slope, Slope Angle, Factor of Safety (FOS).

\section{INTRODUCTION}

The presence of groundwater in surface mining operations often creates serious problems. The most important is generally a reduction in stability of the pit slopes. This is caused by pore water pressures and hydrodynamic shock due to blasting, which reduces the shear strength of the soil. Groundwater and seepage also increase the cost of pit drainage, ripping, drilling and blasting, wear and tear and equipment maintenance. Procedures have been developed in the field of soil mechanics and engineering of dams to obtain quantitative data on pore water pressures and rock permeability, to evaluate the influence of pore water and seepage pressures on stability and to estimate the magnitude of groundwater flow. Based on field investigations, a design can be prepared for the control of groundwater in the slope and in the pit. In the majority of surface mines, groundwater will generally encountered below 50-150 m. The amount of ground water present and the rate, at which it will flow through the rock, depends on many factors. The most important of these are the topography of the area, precipitation and temperature variation, the permeability of the rock mass and overburden soil, and fragmentation and orientation of structural discontinuities in the rock.

\section{CASE STUDY}

A case study were considered from Goan region Practically the entire territory of Goa is covered by rocks of the Dharwar Super Group of the Archaean Proteorozic age except for a narrow strip in the north eastern corner of the territory which is covered by Deccan trap of the Upper Cretaceous-Lower Eocene age. These rocks have essentially suffered green schist facies of metamorphism and have been intruded by granitic rocks followed by basic dykes.

The Mine which is designated as 'Mine $\mathrm{C}$ ' in this paper is located near Advopal/Thivim Village in Bicholim taluka of North Goa.

\subsection{Method of Working}

In Goan region removal of overburden and extraction of ore is proposed to be carried out by opencast method deploying heavy earth moving machinery (HEMM). Depending on the reach of the excavator buckets, it is proposed to keep 7.0 to $8.0 \mathrm{~m}$ high benches with width not less than 10.0 to $12.0 \mathrm{~m}$. Loading of ore is proposed to be done by excavators and wheel loaders in the ore zone and also in the rejection zone in the development of the pit along with ripper-dozer operations. For hauling ore and rejection, 10 tons tippers are proposed to be used.

\subsection{Collection of Baseline Data}

A preliminary investigation was carried out for collection of necessary data for the analysis. During preliminary investigation, identified areas for rock sample collection and recorded its RL. Also data were collected from the mine plan and survey section, which is necessary to study the important surface features of the area.

\subsection{Laboratory Investigations}

Laboratory studies were carried out on the soil/rock samples collected from the field to determine the Density, Cohesion, Angle of Internal Friction, Youngs Modulus and Poisson's Ratio. 


\subsection{Mine Working Parameters}

The overall length of the pit is $400 \mathrm{~m}$ with width of $320 \mathrm{~m}$ and depth $87 \mathrm{~m}$. The RL of top bench is $113 \mathrm{~m}$ whereas the $\mathrm{RL}$ of bottom bench is $26 \mathrm{~m}$. The number of benches in different strata from top to bottom like soil, laterite, phyllitic clay, magniferous clay, magnese ore etc, towards footwall side and hanging wall side are as given in Table 2.1

Table 2.1: Details of number of benches in different strata

\begin{tabular}{|l|l|l|}
\hline S. No. & Strata & $\begin{array}{l}\text { Number } \\
\text { of benches }\end{array}$ \\
\hline Footwall side & 2 \\
\hline 1 & Laterite & 4 \\
\hline 2 & Phyllitic Clay & 5 \\
\hline 3 & Dyke & 2 \\
\hline 4 & Low grade ore & 1 \\
\hline 5 & Powdery ore & 2 \\
\hline Hanging wall side & 3 \\
\hline 1 & Laterite & 1 \\
\hline 2 & Dyke & 1 \\
\hline 3 & Magniferous Clay & \\
\hline 4 & Powdery ore &
\end{tabular}

The total numbers of benches towards footwall side are 14 whereas those in hanging wall side are 7 . The average height of benches is $6 \mathrm{~m}$ with average width of $11 \mathrm{~m}$. The average pit slope towards footwall side is $22^{\circ}-25^{\circ}$ where as that towards hanging wall side is $24^{\circ}$. The mine is being worked below water table

\subsection{Hydrological Details}

The RL of water table in the area is $38 \mathrm{MSL}$. There is no flow of water in the pit during pre-monsoon and dry season. However, during monsoon, the water inflow rate is 8.3 $\mathrm{m}^{3} / \mathrm{hr}$. The surface water inflow during rainy season is of the order of $300 \mathrm{~m}^{3} / \mathrm{hr}$. Maximum quantity of water accumulated during rainy season is $103.05 \times 10^{4} \mathrm{~m}^{3}$ with water column height of $15 \mathrm{~m}$. The number of benches submerged during rainy season is 2 to 3 in number. The post monsoon pumping rate is $10-12 \mathrm{~m}^{3} / \mathrm{hr}$ during the months of November to March. The average reduced level of water is $0.2 \mathrm{~m} /$ day and $1.5 \mathrm{~m} /$ week. The extent of rainfall for 2006 to 2008 is given in Table 2.2

Table 2.2: Rainfall details from 2006 to 2008

\begin{tabular}{|l|l|l|l|l|}
\hline $\begin{array}{l}\text { S. } \\
\text { No. }\end{array}$ & Details & 2006 & 2007 & 2008 \\
\hline 1 & $\begin{array}{l}\text { Daily } \\
\text { maximum }\end{array}$ & $242 \mathrm{~mm}$ & $199 \mathrm{~mm}$ & $233 \mathrm{~mm}$ \\
\hline 2 & $\begin{array}{l}\text { Weekly } \\
\text { average }\end{array}$ & $\begin{array}{l}218.2 \\
\mathrm{~mm}\end{array}$ & $\begin{array}{l}188.10 \\
\mathrm{~mm}\end{array}$ & $\begin{array}{l}152.33 \\
\mathrm{~mm}\end{array}$ \\
\hline 3 & $\begin{array}{l}\text { Monthly } \\
\text { average }\end{array}$ & $\begin{array}{l}872.8 \\
\mathrm{~mm}\end{array}$ & $\begin{array}{l}752.35 \\
\mathrm{~mm}\end{array}$ & $\begin{array}{l}609.34 \\
\mathrm{~mm}\end{array}$ \\
\hline
\end{tabular}

A sever failure involving multiple bench collapse occurred in this mine on $14^{\text {th }}$ August, 2008 involving 12 benches.

\subsection{Lithology}

In general, lithology of the area is as given in Table 2.3

Table 2.3: Lithology of the area from top to bottom

\begin{tabular}{|l|l|}
\hline Lithology & Thickness $(\mathbf{m})$ \\
\hline Laterite & $0-13$ \\
\hline Dyke & $13-52$ \\
\hline Magniferous clay & $52-63$ \\
\hline Powdery ore & $63-80$ \\
\hline Low grade ore & $80-86$ \\
\hline Silicious clay & $86-93$ \\
\hline Chloride schist & $80-103$ \\
\hline
\end{tabular}

\subsection{Laboratory Test Results}

The results of laboratory investigations are given in Table 2.4

Table 2.4: Results of laboratory investigations for rock properties

\begin{tabular}{|l|l|l|l|}
\hline Material & $\begin{array}{l}\text { Dry density } \\
\left(\mathrm{gm} / \mathrm{cm}^{3}\right)\end{array}$ & $\begin{array}{l}\text { Cohesion } \\
(\mathrm{kPa})\end{array}$ & $\begin{array}{l}\text { Angle of } \\
\text { internal } \\
\text { friction(in } \\
\text { degrees })\end{array}$ \\
\hline Dry Condition & 2.55 & 44 & 32 \\
\hline Laterite & 25 & 39 \\
\hline $\begin{array}{l}\text { Magnifero } \\
\text { us clay }\end{array}$ & 1.37 & 30 & 42 \\
\hline Dyke & 1.3 & 22 & 38 \\
\hline $\begin{array}{l}\text { Powdery } \\
\text { ore }\end{array}$ & 2.4 & 18 & 20 \\
\hline Saturated Condition & 14 & 18 \\
\hline Laterite & 2.9 & 16 & 22 \\
\hline $\begin{array}{l}\text { Magnifero } \\
\text { us clay }\end{array}$ & 1.79 & 14 & 24 \\
\hline Dyke & 1.87 & \multicolumn{2}{|l}{} \\
\hline $\begin{array}{l}\text { Powdery } \\
\text { ore }\end{array}$ & 2.64 & & \\
\hline
\end{tabular}

\subsection{Analysis of Slopes of Mine C}

\subsubsection{By Limit Equilibrium Method}

Using GALENA slope stability software, the ultimate pit slope was determined for the pit along Section 1.5P-1.5 $\mathrm{P}^{\prime}$ for south west side for existing and planned pit configurations. Similarly, analysis was done along section 1.5P-1.5 $\mathrm{P}^{\prime}$ for north east side for existing and planned pit configurations.

The results of the laboratory studies given in Table 2.4 were used in the analysis. Bench design parameters from top to bottom for south west side and north east side along Section 1.5P-1.5 $\mathrm{P}^{\prime}$ for existing and planned pit configuration are given in Table 2.5 and Table 2.6 respectively. 
Table 2.5: Bench design parameters from top to bottom towards south west side along section 1.5P-1.5P' for existing and planned pit configuration

\begin{tabular}{|c|c|c|c|c|}
\hline $\begin{array}{l}\text { Name of } \\
\text { the mine }\end{array}$ & $\begin{array}{l}\text { Section } \\
\text { under } \\
\text { investig } \\
\text { ation }\end{array}$ & $\begin{array}{l}\text { Height } \\
\text { (m) }\end{array}$ & $\begin{array}{l}\text { Width } \\
\text { (m) }\end{array}$ & $\begin{array}{l}\text { Slope } \\
\text { angle } \\
\left({ }^{\circ}\right)\end{array}$ \\
\hline \multirow{20}{*}{ Mine $\mathrm{C}$} & \multirow{10}{*}{$\begin{array}{l}\text { Existing } \\
\text { pit } \\
\text { configur } \\
\text { ation }\end{array}$} & 4 & 8 & 15 \\
\hline & & 5 & 9 & 59 \\
\hline & & 5 & 5 & 59 \\
\hline & & 5 & 7 & 55 \\
\hline & & 5 & 8 & 51 \\
\hline & & 3 & 8 & 45 \\
\hline & & 10 & 25 & 63 \\
\hline & & 3 & 4 & 3 \\
\hline & & 3 & 7 & 36 \\
\hline & & 6 & - & 56 \\
\hline & \multirow{10}{*}{$\begin{array}{l}\text { Planned } \\
\text { pit } \\
\text { configur } \\
\text { ation }\end{array}$} & 4 & 4 & 53 \\
\hline & & 3 & 7 & 56 \\
\hline & & 4 & 5 & 69 \\
\hline & & 5 & 10 & 78 \\
\hline & & 5 & 7 & 42 \\
\hline & & 5 & 9 & 59 \\
\hline & & 6 & 7 & 71 \\
\hline & & 4 & 9 & 63 \\
\hline & & 4 & 8 & 53 \\
\hline & & 6 & - & 63 \\
\hline
\end{tabular}

Table 2.6: Bench design parameters from top to bottom towards north east side along section $1.5 \mathrm{P}-1.5 \mathrm{P}^{\prime}$ for existing and planned pit configuration

\begin{tabular}{|c|c|c|c|c|}
\hline $\begin{array}{l}\text { Name } \\
\text { of the } \\
\text { mine }\end{array}$ & $\begin{array}{l}\text { Section } \\
\text { under } \\
\text { investig } \\
\text { ation }\end{array}$ & $\begin{array}{l}\text { Height } \\
\text { (m) }\end{array}$ & $\begin{array}{l}\text { Width } \\
\text { (m) }\end{array}$ & $\begin{array}{l}\text { Slope } \\
\text { angle }\left({ }^{\circ}\right)\end{array}$ \\
\hline \multirow{15}{*}{ Mine $\mathrm{C}$} & \multirow{6}{*}{$\begin{array}{l}\text { Existin } \\
\mathrm{g} \text { pit } \\
\text { configu } \\
\text { ration }\end{array}$} & 3.0 & 21 & 18 \\
\hline & & 4.0 & 28 & 36 \\
\hline & & 4.0 & 24 & 32 \\
\hline & & 2.0 & 8 & 45 \\
\hline & & 4.0 & 10 & 36 \\
\hline & & 5.0 & - & 38 \\
\hline & \multirow{9}{*}{$\begin{array}{l}\text { Planned } \\
\text { pit } \\
\text { configu } \\
\text { ration }\end{array}$} & 1.0 & 6 & 71 \\
\hline & & 2.0 & 6 & 71 \\
\hline & & 2.0 & 5 & 71 \\
\hline & & 3.0 & 5 & 63 \\
\hline & & 2.0 & 12 & 36 \\
\hline & & 2.5 & 5 & 63 \\
\hline & & 3.0 & 5 & 63 \\
\hline & & 3.0 & 4 & 59 \\
\hline & & 2.5 & - & 63 \\
\hline
\end{tabular}

\subsubsection{Slope Stability Analysis for Saturated}

\section{Condition}

Figure.2.1 shows the analysis of slope along Section 1.5P$1.5 \mathrm{P}^{\prime}$ towards southwest side for existing pit configuration. The limit in $\mathrm{x}$-direction is $260 \mathrm{~m}$ and in y-direction it is 120 $\mathrm{m}$. As can be seen, in this section, only one type of materials is encountered. The factor of safety along this section is 2.43 which show that the slope is stable.

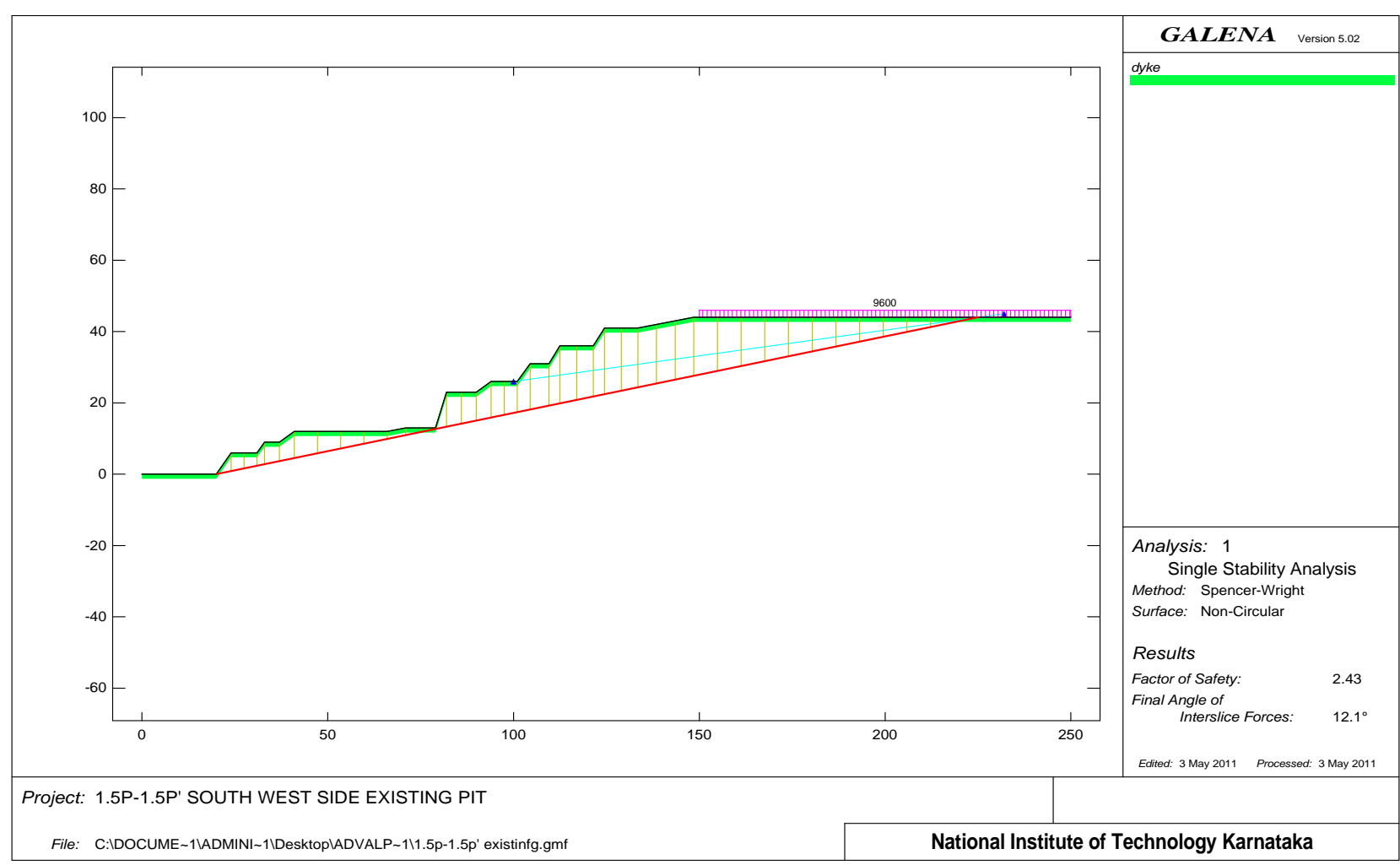

Fig. 2.1 Stability analysis along section 1.5P-1.5P' southwest side for existing pit configuration 
Figure.2.2 shows the analysis of slope along Section 1.5P$1.5 \mathrm{P}^{\prime}$ towards southwest side for planned pit configuration. The limit in $\mathrm{x}$-direction is $260 \mathrm{~m}$ and in y-direction it is 130 m. Every material has been shown by different colours for their unique identification. Further, every material in the slope has different cohesion and angle of internal friction values as determined from the laboratory studies. As can be seen, in this section, two different types of materials are encountered. The factor of safety along this section is 1.03 which shows that the slope is not stable.

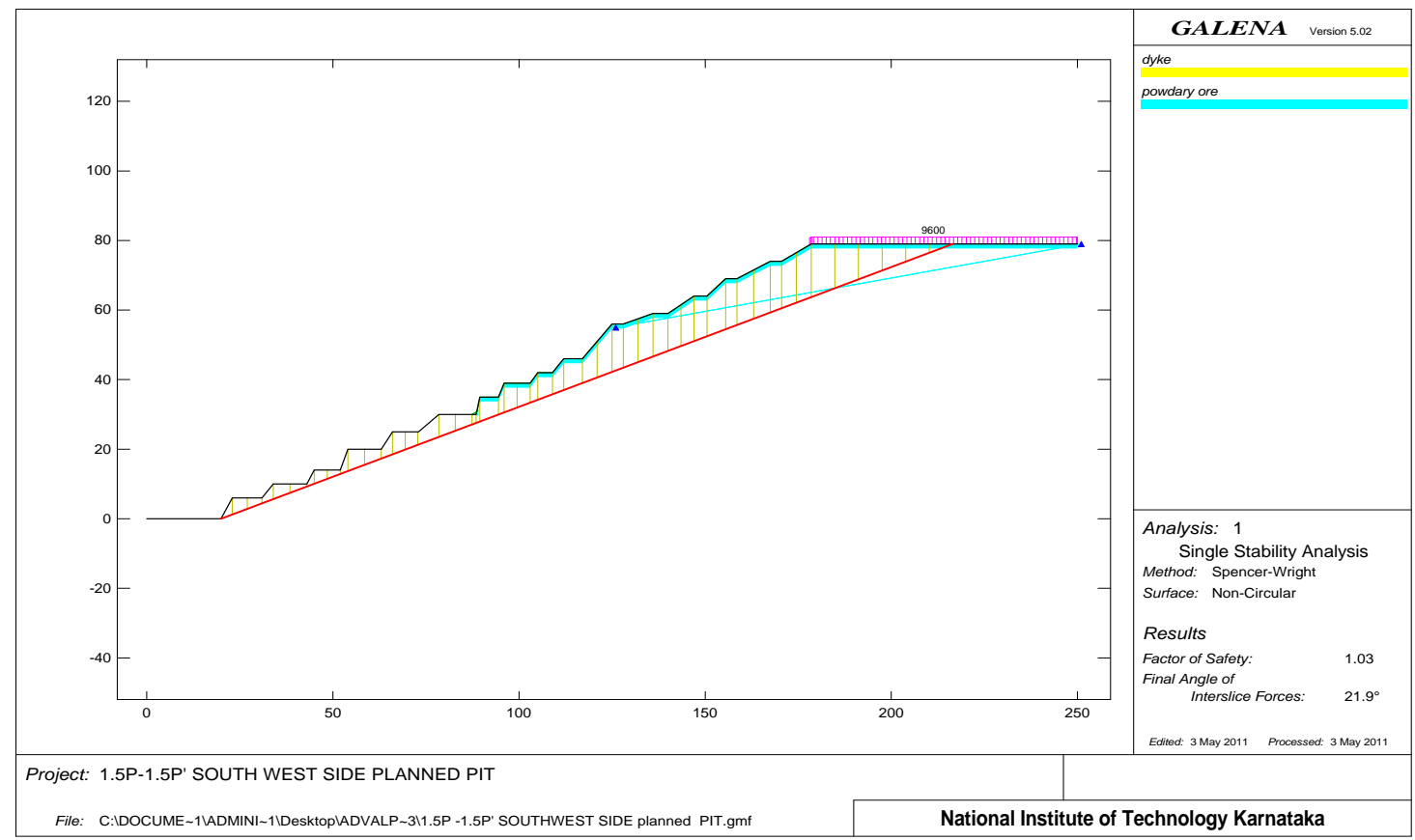

Fig. 2.2 Stability analysis along section 1.5P-1.5P' southwest side for planned pit configuration

Figure.2.3 shows the analysis of slope along Section 1.5P$1.5 \mathrm{P}^{\prime}$ towards northeast side for existing pit configuration. The limit in $\mathrm{x}$-direction is $210 \mathrm{~m}$ and in y-direction it is 80 $\mathrm{m}$. Every material has been shown by different colours for their unique identification. Further, every material in the slope has different cohesion and angle of internal friction values as determined from the laboratory studies. As can be seen, in this section, four different types of materials are encountered. The factor of safety along this section is 22.03 which show that the slope is stable.

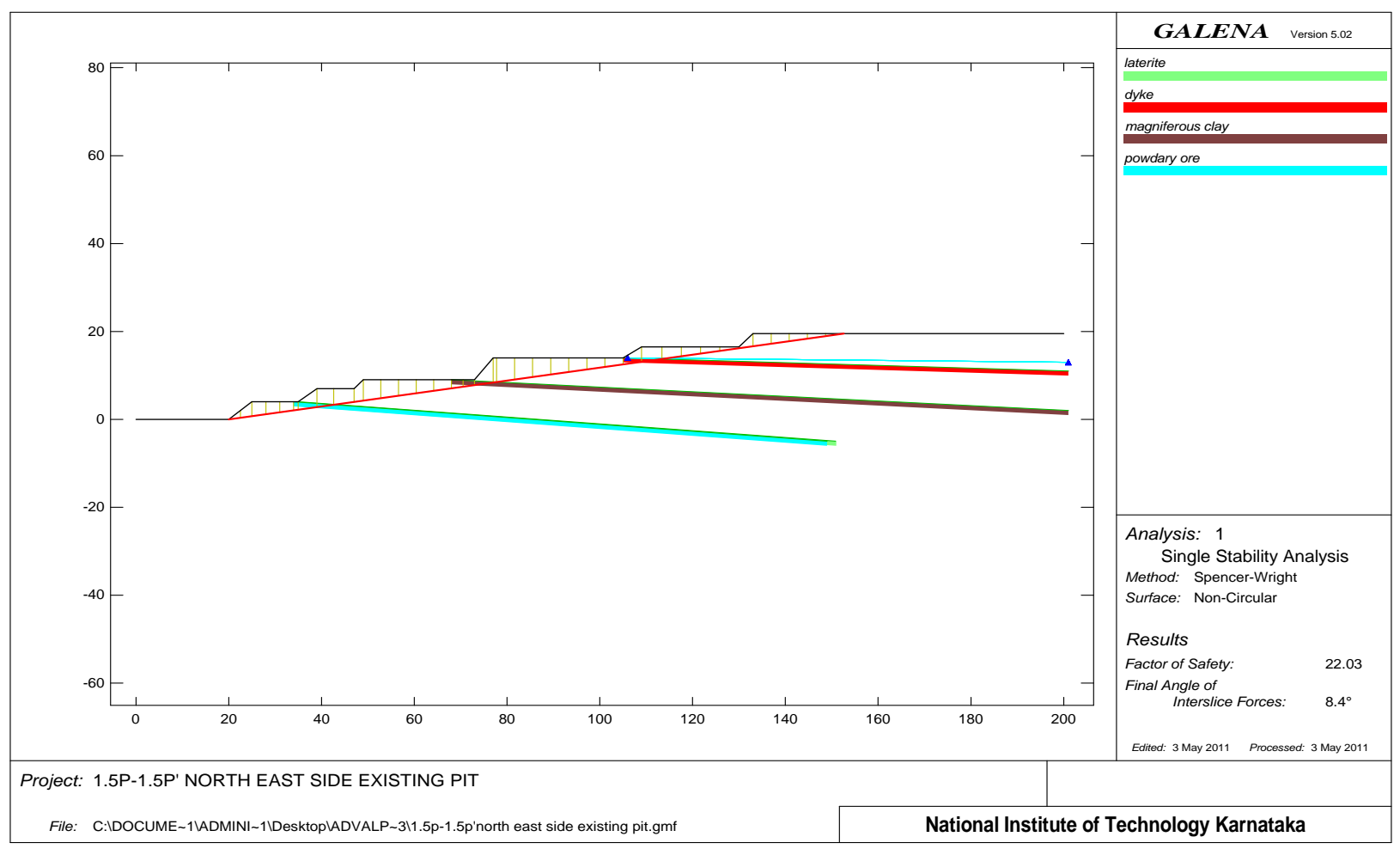

Fig.2.3 Stability analysis along section 1.5P-1.5P' northeast side for existing pit configuration 
Figure.2.4 shows the analysis of slope along Section 1.5P$1.5 \mathrm{P}^{\prime}$ towards northeast side for planned pit configuration. The limit in $\mathrm{x}$-direction is $160 \mathrm{~m}$ and in y-direction it is 80 $\mathrm{m}$. Every material has been shown by different colours for their unique identification. Further, every material in the slope has different cohesion and angle of internal friction values as determined from the laboratory studies. As can be seen, in this section, four different types of materials are encountered. The factor of safety along this section is 4.75 which show that the slope is stable.

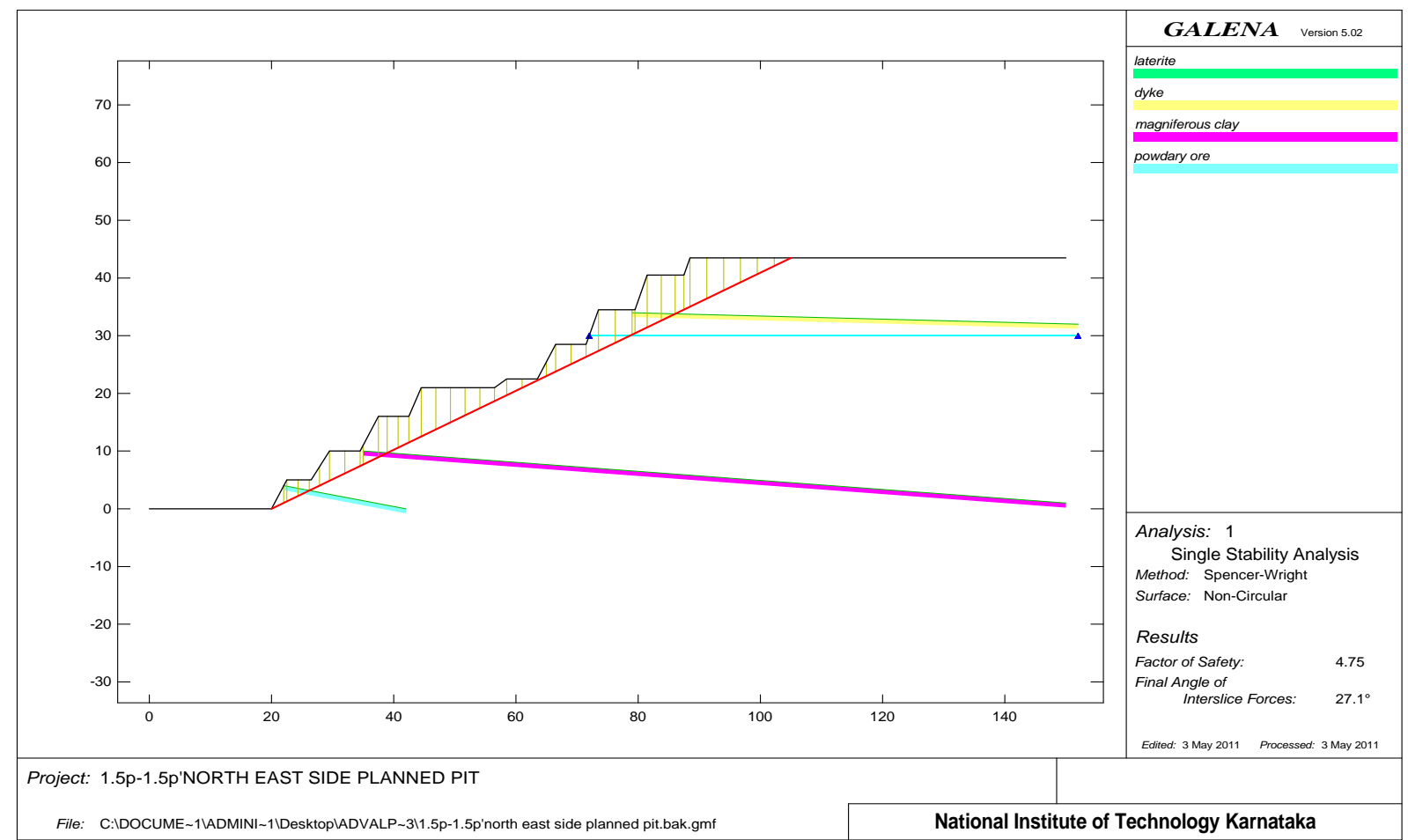

Fig.2.4 Stability analysis along section 1.5P-1.5P' northeast side for planned pit configuration

A summary of ultimate pit slope angle and factor of safety along Section 1.5P-1.5P' towards southwest and northeast side for existing and planned pit configurations is given in Table 2.7

Table 2.7: Summary of ultimate pit slope angle and factor of safety along section $1.5 \mathrm{P}-1.5 \mathrm{P}^{\prime}$ towards southwest and northeast side for existing and planned pit configurations

\begin{tabular}{|l|l|l|l|l|}
\hline Section & \multicolumn{2}{|l|}{$\begin{array}{l}\text { Ultimate Pit Slope } \\
\text { Angle } \\
\text { (in degrees) }\end{array}$} & \multicolumn{2}{l|}{ Factor of Safety } \\
\cline { 2 - 5 } & Existing & Planned & Existing & Planned \\
\hline Saturated Condition & 19 & 22 & 2.43 & 1.03 \\
\hline $\begin{array}{l}1.5 \mathrm{P} 1.5 \mathrm{P}^{\prime} \\
\text { Southwest side }\end{array}$ & 10 & 32 & 22.03 & 4.75 \\
\hline $\begin{array}{l}1.5 \mathrm{P}-1.5 \mathrm{P}^{\prime} \\
\text { Northeast side }\end{array}$ & & & & \\
\hline
\end{tabular}

\subsection{Some Recommendations for Safety of Mine}

\section{Slopes}

1. It is recommended to monitor the movements of ground regularly, wherever the dyke is present in the highwall.

2. Is recommended to maintain a safe distance between crest of top bench and toe of external load (like old dumps, hillock, stack yard etc.) existing above the highwall. For example, as a thumb rule this distance may be equal to sum of depth of pit and height of dump.
3. It is recommended to maintain and monitor proper drainage system especially in low bearing capacity types of clay zone during the monsoon. In this zone, the bench height should be restricted to a maximum of $4 \mathrm{~m}$ only.

4. It is required to maintain proper drainage system in top benches, especially above clay benches, so as to avoid formation of gully in bottom benches and further its erosion.

5. As far as possible height of clay benches should not exceed $4 \mathrm{~m}$ with minimum of $5 \mathrm{~m}$ width.

6. Extra precaution has to be taken in limonitic clay benches, contains friable silica, which will flow readily when it is saturated with water.

7. Wherever the horizontal boreholes are present at the face, there should be proper lining of path of water flow, so as to avoid percolation of water into the ground. This can be easily achieved by spreading polythene sheets all along the length of water flow.

\subsection{Conclusion}

Based on the available results, following conclusion was drawn Limit equilibrium method provides quick results and easy in computation. Cohesion and angle of internal friction are important factors affecting slope stability. With increase in both these parameters the stability of slopes increases. It is also felt that the results of physico-mechanical properties of rocks reported in this work may be used for design of 
slopes in and around Goa region or areas with similar lithology.In general, there are slope failures below the horizontal boreholes, which are drilled for depressurization of highwall. These types of local failures are severe in clay benches. Drilling of vertical boreholes is considered as the most effective mode of depressurization of highwalls. However, in hilly terrains, like as topography available in Goan region, because of large overburden, this method may not be practical

\section{REFERENCES}

[1] Abramson, L. W., Lee, T. S., Sharma, S and Boyce, M. G., (2001); "Slope stability and stabilisation methods", Second edition. A Wiley Interscience, USA.

[2] Au, S. W. C., (1998); "Rain-induced slope instability in hongkong”, Engineering Geology, Vol. 51, pp 1-36.

[3] Bujang, B. K., Faisal, H. Ali and Low, T. H., (2006); "Water infiltration characteristics of unsaturated soil slope and its effect on suction and stability", Geotechnical and Geological Engineering, Vol. 24, pp 1293-1306.

[4] Chang, M., Chiu Y., Lin, S and Ke, T., (2005); "Preliminary study on the 2003 slope failure in woowan-chai Area, Mt. Ali Road, Taiwan”, Engineering Geology, Vol. 80, pp 93-114.

[5] Cho, S. E and Lee, S. R., (2001); "Instability of unsaturated soil slopes due to infiltration", Computers and Geotechnics, Vol. 28 pp 185-208.

[6] Furuya, G., Suemine, A., Sassa, K., Komatsubara, T., Watanabe, N and Marui, H., (2006); "Relationship between groundwater flow estimated by soil temperature and slope failures caused by heavy rainfall, Shikoku Island, south-western Japan”, Engineering Geology, Vol. 85, pp 332-346.

[7] Gasmo, J. M., Rahardjo, H and Leong, E. C., (2000); "Infiltration effects on stability of a residual Soil slope", Computers and Geotechnics, Vol. 26, pp 145165.

[8] Gavin, K and Xue, J., (2008); "A simple method to analyze infiltration into unsaturated soil slopes", Computers and Geotechnics, Vol. 35, pp 223-230.

[9] Gerscovich, D. M. S., Vargas, E. A and Decampos, T. M. P., (2006); "On the evaluation of unsaturated flow in a natural slope in Rio de Janeiro, Brazil", Engineering Geology, Vol. 88, pp 23-40.

[10] Hoek and Bray J. W., (1981) "Rock slope engineering", Third edition. Institution of Mining and Metallurgy, UK.

[11] Huang, M and Jia, C., (2009); "Strength reduction FEM in stability analysis of soil slopes subjected to transient unsaturated seepage", Computers and Geotechnics, Vol. 36, pp 93-101.

[12] Jeong, S., Kim, J and Lee, K., (2008); "Effect of clay content on well-graded sands due to infiltration", Engineering Geology, Vol. 102, pp 74-81.

[13] Jiao, J., Wang, X and Nandy, S., (2005); "Confined groundwater zone and slope instability in weathered igneous rocks in Hong Kong”, Engineering Geology, Vol. 80, pp 71-92.
[14] Lee, Y and Hungming., (2007); “Assessing slope protection methods for weak rock slopes in South western Taiwan", Engineering Geology, Vol. 91, pp 100-116.

[15] Matsuura, S., Asano, S and Okamoto, T., (2008); "Relationship between rain and/or melt water, porewater pressure and displacement of a reactivated landslide", Engineering Geology, Vol. 101, pp 49-59.

[16] Mehmet, B., (2007); "Investigation of stability of slopes under drawdown conditions", Computers and Geotechnics, Vol. 34, pp 81-91.

[17] Ng, C. W. W and Shi, Q., (1998); “A Numerical investigation of the stability of unsaturated soil slopes subjected to transient seepage", Computers and Geotechnics, Vol. 22, pp 1-28.

[18] Oh, T and Vanapalli, S., (2010); "Influence of rain infiltration on the stability of compacted soil slopes", Computers and Geotechnics, Vol. 37, pp 649-657.

[19] Rahardjo, H., Hritzuk, K. J., Leong, E. C and Rezaur, R. B., (2003); "Effectiveness of horizontal drains for slope stability", Engineering Geology, Vol. 69, pp 295308.

[20] Tofani, V. S., Dapporto, P., Vannocci and Casagli, N., (2005); “Analysis of infiltration, seepage processes and slope instability mechanisms during the November 2000 storm event in Tuscany", Advances in Geosciences, Vol. 2, pp 301-304.

[21] Zhang, X., Zhu, Y and Fang, C., (2009); "The role of fore air flow in soil slope stability analysis", Journal of Hydrodynamics, Vol. 21, pp 640-646. 